\title{
BASIC NEEDS IN OTHER CULTURES: USING QUALITATIVE METHODS TO STUDY KEY ISSUES IN SELF-DETERMINATION THEORY RESEARCH
}

\author{
M.F. LYNCH ${ }^{\mathrm{a}, \mathrm{b}, \mathrm{c}}$, N.R. SALIKHOVA ${ }^{\mathrm{b}}$, A.V. EREMEEVA ${ }^{\mathrm{b}}$ \\ ${ }^{a}$ University of Rochester, 500 Joseph C. Wilson Blvd., Rochester, New York, 14627, USA \\ ${ }^{b}$ Kazan Federal University, 18 Kremlyovskaya Str., Kazan, 420008, Russian Federation \\ ${ }^{c}$ National Research University Higher School of Economics, 20 Myasnitskaya Str., Moscore, 101000, \\ Russian Federation
}

\begin{abstract}
Self-Determination Theory (SDT) has grown substantially over the past 30 years. Much of that growth stems from the theory's rigorous empirical foundations and the elegance of the theory itself. Yet most of SDT's empirical support has been quantitative, with little attention to the possible contributions of a qualitative approach. This paper details two recent, qualitative studies of motivation in the realm of education that address critical issues in SDT. Study $1(\mathrm{~N}=195)$ explored the question, "Might there be different basic needs in other cultures?". Study 2 (N = 115 ) asked, "What is the experience of autonomy like for members of another culture?". In Study 1 , an analysis of responses given by 195 teachers, psychologists and school principals of the Republic of Tatarstan (Russia) revealed their consensus that the child's psychological well-being is based on satisfying the child's need for relationships. In Study 2, 115 graduate students (Kazan, Russia) described their experience of autonomy and non-autonomy at the university in the form of an essay. Analysis revealed two additional categories that distinguish these situations from each other: the time factor and the meaning of the situation for a person. In both studies, participants provided responses in their own words. These studies provide simple examples of how a qualitative design can push the boundaries of current understanding with respect to two central questions under cross-cultural debate. Suggestions for further research are offered.
\end{abstract}

Keywords: self-determination theory, qualitative methods, motivation, education, autonomy, basic psychological needs.

\section{Introduction}

Self-Determination Theory (SDT) has enjoyed widespread growth over the past 30 years as a theory of motivation, personality, and development. Much of that growth stems as much from the rigorous nature of the theory's empirical foundations as from the parsimony and elegance of the theory itself. Yet, with some exceptions (e.g., Chirkov \& Anderson, 2018), most of the theory's empirical support has

The study has been funded by the Russian Academic Excellence Project ' $5-100$ '. With respect to the contributions of Martin F. Lynch, the article was prepared within the framework of the Higher School of Economics University Basic Research Program. 
been quantitative, with little attention paid to the possible contributions of a qualitative approach. In the present paper, we explore how the use of qualitative methods can push the boundaries of self-determination theory with respect to two central questions: (1) basic psychological needs: how many are there, and are they, as SDT claims, truly universal? And (2) autonomy: is it the same for everyone, regardless of differences in culture? These are important questions, because SDT makes specific and rather strong claims about these constructs, and quantitative methods only go so far in providing the empirical support needed for these claims. Before explaining how the present paper will address these issues, we highlight SDT's claims with respect to the constructs of basic psychological needs, broadly speaking, and of autonomy, more specifically.

\section{Self-Determination Theory and Basic Psychological Needs}

As noted, SDT makes rather strong claims regarding the construct of basic psychological needs (BPNs; Deci \& Ryan, 1985; Ryan \& Deci, 2017). Briefly, BPNs are the nutrients that are essential in order for the organism, that is, the human person, to grow, to develop, to integrate experiences, and to experience well-being. In other words, when needs are fulfilled or satisfied, they lead to growth, integration, and well-being. The converse is also true: in situations of need deprivation or needthwarting, the person experiences degradations in growth and well-being. We note that this is a strong definition of a need: the emphasis is on that which is in fact essential; a need is more than a want, a desire, or a preference. A person may or may not be consciously aware of a need, but its fulfilment remains essential in order for real growth and well-being to occur, precisely because, according to SDT, a need, so-called, is an organismic requirement. Motivation is also posited to be affected by need satisfaction: when needs are fulfilled in a particular context, then motivation for activity in that context tends to be more internal (i.e., autonomous, volitionally engaged, personally chosen) whereas when needs are lacking in fulfilment or even thwarted, motivation tends to be more external (i.e., controlled, engaged under feelings of pressure or obligation rather than personally chosen). SDT posits and research (primarily quantitative) supports the existence of three such BPNs: the needs for relatedness, for competence, and for autonomy.

Relatedness recognizes that humans, in a fundamental sense, are social beings; we require the presence of positive and mutually supportive relationships with other human beings for our survival. Competence reflects the importance of feeling that one is capable of having an impact on the surrounding world, of attaining desired outcomes by means of one's actions. Autonomy pertains to the importance of feeling that one can take the initiative, make personally important choices, endorse at a deep level one's actions and values.

SDT argues that these three needs are based in the evolution of the human species (Ryan, Kuhl, \& Deci, 1997); consistent with that position, the needs are considered to be requirements for all human beings. In other words, SDT posits the additional strong claim that the BPNs are universal across cultures. The specific ways the needs are satisfied may differ from person to person and from culture to 
culture (Chirkov, Ryan, \& Sheldon, 2011), but they remain universally essential requirements for growth, integration, and well-being. The theory remains open to the possibility that other basic needs may be discovered, but it is adamant about the empirically testable claim embedded within the strong definition of a need elaborated above: that satisfaction of the needs leads to growth, integration, wellbeing, and internal motivation, but that the thwarting or deprivation of needs leads to degradations in these important human outcomes. Thus far no additional needs beyond the three initially proposed by SDT (Deci \& Ryan, 1985) have been unequivocably supported in the literature (Ryan \& Deci, 2017). As noted, whether SDT's three basic needs apply in other cultures has been tested nomothetically, using quantitative measures and methods (e.g., Chirkov, 2009; Chirkov et al., 2011; Jang, Reeve, Ryan, \& Kim, 2009; Zhou, Ma, \& Deci, 2009). Study 1 in the present paper explores SDT's claim ideographically, through qualitative methods. Specifically, we wish to explore whether people in other cultures might possibly have different basic needs. We will say more about this, below.

Of SDT's three canonical needs, autonomy has been the most controversial over the years. In part, this is because autonomy is often conflated with another construct, independence, and it seems contradictory to suggest that both independence (the feeling that I can do things on my own, without others' help) and relatedness (the awareness of others' importance to me) could be needs, in the strong sense of that term proposed by SDT. Alternatively, some have argued that autonomy cannot be a need in cultures that do not explicitly value autonomy (e.g., Markus \& Kitayama, 1991). Although SDT theorists have pointed out that the construct of autonomy, derived from existentialist sources, is conceptually distinct from independence (e.g., Chirkov et al., 2011; Ryan \& Deci, 2017), and have demonstrated empirically, through quantitative methods, (1) that autonomy and independence are orthogonal constructs (e.g., Lynch, 2013; Ryan \& Lynch, 1989) and (2) that the experience of autonomy meets the criterion for a need (i.e., promoting well-being and intrinsic motivation when satisfied) for people living in quite varied cultural contexts (e.g. Lynch, La Guardia, \& Ryan, 2009), the controversy remains. For this reason, Study 2 in the present paper explores the nature and universality of autonomy from a qualitative perspective, by asking people in another culture to tell us, in their own words, what the experience of autonomy is like for them.

We wish to suggest that a qualitative approach permits us to ask questions we do not usually ask when we are operating from within a strictly quantitative methodology; the answers we receive might allow us to understand our theoretical constructs in new and possibly deeper ways, leaving open the possibility of both challenging and strengthening the theory, itself. The issue, in other words, has to do with testing a theory at its boundaries in order to promote growth. To this end, we provide here a brief overview of two rather simple, qualitatively informed studies that we conducted in order to test these two questions (might people in a different culture have different needs? What is the experience of autonomy like in anther culture?). 


\section{Study 1: Do people in a Different Culture Have Different Basic Psychological Needs?}

How would we find out whether people in a different culture have different BPNs? As an initial attempt to answer this question, it struck us as reasonable to ask people who are considered 'experts' in the local culture what they considered to be the essential nutriments for growth and well-being - that is, people who are both from and in that culture, and who have a relevant, professional expertise, such as teachers, for example. For the purpose of illustration, we here present a small portion of a previously published study; for full details, we refer the reader to that account (Lynch \& Salikhova, 2017).

Participants and procedures. In this study, 195 participants (92\% female) were recruited from a continuing education and recertification program from cities across the Republic of Tatarstan, within the Russian Federation. Participants were practicing educators (age range 20-70 years old, $M=35$ ), including teachers of various subject matters $(73.4 \%)$, psychologists $(7.2 \%)$, school administrators $(1.5 \%)$, and methodologists (1\%); the remaining participants did not report their profession. These educators reported working with children and young people of various ages, from $0-3$ years old $(9.7 \%)$, from $4-7$ years old (15.4\%), from 7-16 years old (43.6\%), and older than $16(19.5 \%)$.

Materials. All materials were presented in Russian. Participants were asked to respond, in their own words, to the following prompt: "For normal development the organism needs to satisfy biological needs for food, water, warmth. For the normal development of the person the satisfaction of psychological needs is necessary. Write down what in your view are the three most important needs that are vitally essential for the development of a psychologically healthy person."

Analytic strategy. We employed a two-fold strategy to analyze the responses generated by participants. First, we looked at word/concept frequencies. Because we are both primarily quantitative researchers, we considered it important to determine which words or concepts appeared most frequently in the lists provided by the local teacher-experts; presumably it would be meaningful and noteworthy if some ideas appeared more often than others. As a second step, we had a group of four independent raters read through and organize participant responses using a modified Q-sort technology. They were instructed to organize the words and phrases into groups, based on similarity. These raters were native speakers of Russian, all with an education in psychology, who were otherwise blind to the study's details.

\section{Study 1: Selected Results}

Our teacher-experts provided 444 responses to the open-ended prompt regarding "the most important needs... vitally essential for the development of a psychologically healthy person." As noted, in the first stage of analysis we looked for words or concepts that appeared most frequently in the lists created by participants. Specifically, each time a word or its related root appeared, it was counted. 
When asked what they consider to be the most essential needs for healthy psychological development, these local experts listed the following, in descending order of frequency (frequencies in parentheses): communication (42), love (39), understanding (21), family (15), respect (11), care (10), attention (8), support (8), and so on. (For the full list, see Lynch \& Salikhova, 2017).

For the second step, four independent raters were asked to sort participant responses into as many categories as they felt were needed. (Note that exact duplicates were removed before presenting raters with the list of teacher responses.) The most frequently occurring categories identified by the raters were as follows (number of unique participant responses reflecting that category provided in parentheses): Rater 1: favorable family (19 responses); Rater 2: family wellbeing (23 responses); Rater 3: family (14 responses); Rater 4: family (42 responses). The next most frequently occurring categories were: self-development (Rater 1, 14 responses); self-realization (Rater 2, 41 responses); development/self-development (Rater 3, 19 responses); aspects of development and self-development (Rater 4, 15 responses). The third most frequently occurring categories were: social aspect of personality development (Rater 1, 26 responses); social sphere (Rater 2, 11 responses); social component (Rater 3, 19 responses); social factors (Rater 4, 20 responses). (For full results, see Lynch \& Salikhova, 2017.)

\section{Study 1: Brief Discussion}

When asked to tell us in their own words what they believe is essential for children's growth and well-being (in other words, what they consider to be 'basic psychological needs,' as SDT defines that construct), these local experts emphasized themes having to do with relationships. This finding emerged whether the data were analyzed by means of frequency counts of words and concepts, or whether they were analyzed by independent raters using a modified Q-sort technology. In short, local experts, in a culture as yet uninvestigated from an SDT-perspective, identified relationships as a basic psychological need, corroborating one of the three needs posited by SDT on theoretical and quantitative empirical grounds. We move on now to Study 2.

\section{Study 2: What is the Experience of Autonomy Like in Another Culture?}

Consistent with our approach in Study 1, we considered that a reasonable way to find out what autonomy looks and feels like in another culture would be to ask people from that culture to tell us about it in their own words. In this study, our local experts were doctoral students. We report here only a small portion of an asyet unpublished study.

Participants and procedures. Participants were first-year students $(N=115,49 \%$ women; age $M=24.7$ years, $S D=3.2$ ) enrolled in one of several doctoral programs at a major university in the Republic of Tatarstan, located within the Russian Federation, from biological sciences, computational mathematics, physics and astronomy, earth sciences, and chemical sciences. All participants were native speakers of Russian. 
Materials. All measures were administered in Russian. Participants were asked to write a three-part essay about some activity they engaged in while at the university; for each part of the essay, a prompt was provided. The autonomy prompt asked them to describe a situation in which they themselves decided to do something at the university and took the initiative in doing so. The non-autonomy prompt asked them to describe a situation when they did something not because they wanted to do it, but because they had to do it. They were asked to describe the situations in detail such that the reader could experience it with them. Then they were asked to compare situations, noting any similarities and differences.

Analytic strategy. A two-stage content analysis of participant responses was carried out separately by two native speakers of Russian with advanced training in psychology. The first stage consisted of identifying key words; the second stage involved identifying key themes and categories that emerged from those key words.

\section{Study 2: Selected Results}

Our experts, doctoral students, identified and wrote about 230 situations (115 situations of autonomy, 115 situations of non-autonomy) in their experience at university. The general types of activity that emerged in these responses included academic activity (for example, classroom experiences), representing $15 \%$ of the autonomous and $26.3 \%$ of the non-autonomous situations; scientific or researchspecific activity (24.5\% of autonomous, $16 \%$ of non-autonomous situations); social activity ( $8.2 \%$ of autonomous, $6 \%$ of non-autonomous situations); creative activity ( $0.9 \%$ of autonomous, $0.9 \%$ of non-autonomous situations); sports activity $(0.9 \%$ of autonomous, $0.9 \%$ of non-autonomous situations); and other ( $0.4 \%$ of autonomous situations).

In the content analysis, our two expert raters identified (separately, but followed by consultation) 13 themes or categories in the participant responses. Their labels for these categories were: emotional manifestations, psychophysiological manifestations, intellectual-emotional manifestations, volitional efforts, value of the situation for the subject, factor of time in the situation (e.g., perception of time, speed of working, procrastination), optimalness of conditions with respect to the activity (e.g., immersion in the work, passion), discovery of the author's creative potential, attribution of success or failure to internal or external factors, influence of the situation on relationships of the subject with other people, remembering or forgetting of material obtained in the situation, influence of the situation on the identity and/or self-esteem of the author, and application of the experience gained in one's further life.

Here are a few sample responses that fall under the researcher-generated heading of 'emotional manifestations':

"I felt an emotional uplift, feeling that everything is in my hands," "I experienced something like hopelessness and despair," "a feeling of euphoria was seeping through me," "I felt emptiness, disappointment in myself, all these destructive emotions accumulated in my thoughts at that moment," "I experienced such pride in myself, as if I 
were receiving the Nobel Prize," "I experienced a special joy and satisfaction in my work."

For present purposes, we focus only on the doctoral students' responses that fall under the category of emotional manifestations. Emotions that could be described as 'positive' included joy, pride, inspiration, happiness, relief, pleasure, and satisfaction. Those that could be described as 'negative' included 'absence of joy,' 'fear,' 'shame,' 'anxiety,' 'guilt,' 'melancholy,' 'irritation,' 'disappointment,' and 'sadness.' When comparing the predominance of the various emotions within the doctoral students' essays, it became clear that those situations described in response to the autonomy prompt were substantially more likely to reflect positive than negative emotions, whereas the opposite was the case for situations generated in response to the non-autonomy prompt: participants characterized autonomy situations by 'joy' nearly four times more often than they did non-autonomy situations; autonomy situations were characterized by 'pride' 16 times more frequently, by 'happiness' four time more frequently, by 'pleasure' fourteen times more frequently, and so on. On the other hand, when describing non-autonomy situations they were more than three times more likely to include 'shame,' more than eight times more likely to include 'anger,' and so on. We point out that participants were almost equally likely to characterize situations of autonomy and non-autonomy in the university as 'fearful.'

There were other notable differences between how doctoral students described situations of autonomy and situations of non-autonomy in the university, in terms of the various categories identified by the independent raters (psychophysiological manifestations, volitional efforts, discovery of one's creative potential, and so on). Here we simply call attention to two additional categories in which interesting differences emerged: the time factor, and the value of the situation to the individual. Specifically, doctoral students were more likely to characterize experiences of autonomy as involving an accelerated perception of time, a high speed of work, and less procrastination; the opposite was true of the non-autonomy situations. As well, although both autonomy and non-autonomy situations were described as useful (autonomy situations somewhat moreso), only non-autonomy situations were also described as useless. There were clear differences in these and other categories between situations of autonomy versus situations of non-autonomy in the university. Importantly, many of these categories reflect aspects of the experience of autonomy that do not typically make it into official definitions of the construct.

\section{Study 2: Brief Discussion}

When we asked people in another culture, one not typically investigated by SDT researchers, to tell us in their own words what the experience of autonomy felt like to them, in what for them was a real-world, ecologically valid context (as the university would be to doctoral students), we found our understanding of a key construct like 'autonomy' becoming a bit richer. Dimensions of the experience not typically included in official definitions of the construct (e.g., time factor, psychophysiological manifestations, intellectual-emotional manifestations, attribution 
of success or failure to internal or external factors, and so on) emerged as important markers distinguishing experiences of autonomy from experiences of non-autonomy.

\section{General Discussion}

In this paper, we presented a brief overview of two relatively simple, qualitatively informed studies in order to explore ways in which a qualitative approach might begin to push the existing boundaries of a well-established theory, such as Selfdetermination theory (SDT), whose empirical support thus far has rested primarily (and almost exclusively) on quantitative foundations.

Study 1 asked whether people in a different culture might have different or perhaps additional basic psychological needs than the three needs proposed by SDT for competence, relatedness, and autonomy. We found that when teachers, considered to be local experts (that is, experts both with respect to their own culture, and with respect to their professional expertise in human development), were asked what they believed to be vitally important for healthy psychological development, they told us first and foremost that relationships are essential. This finding held, both when teacher responses were considered in terms of frequency counts, and when independent raters classified the teachers' responses. It seems possible to interpret this result as confirmation of one of the basic psychological needs proposed by SDT: the need for relatedness, or mutually meaningful and supportive relationships (for quantitative support, see, e.g., Lynch \& Salikhova, 2016). Of course, technically speaking a further test should be made of any candidate need suggested by a group of local experts: especially had the local experts suggested as a need something not within SDT's canonical list of three (competence, relatedness, autonomy), the next logical step would be to test empirically, perhaps through traditional quantitative means, whether that candidate need does in fact promote the outcomes of growth, integration, well-being, and internal motivation when it is satisfied (or, conversely, the degradation of those outcomes, when the candidate need is deprived or thwarted).

The focus of Study 2 was on the need for autonomy. Specifically, we asked doctoral students to describe activities which SDT would consider to reflect autonomy and those which would reflect non-autonomy (the word 'autonomy' was not used in the prompts to which participants responded) when in a context, the university, which should presumably have high ecological validity for them. We were interested in whether, in the responses they provided, patterns would emerge to suggest what the experience of autonomy is like for people in a culture that to date has been little studied by SDT researchers (specifically, Tatar), and whether that might shed any light on our understanding of the construct, itself. It did. Autonomous and non-autonomous activities differed from each other in notable ways, in terms of things like emotional and psychophysiological manifestations, volitional efforts, value of the situation, factor of time in the situation (including things like perception of time, speed of working, procrastination), and so on. Importantly, some of these dimensions are not typically captured by the standard definition of the construct of autonomy. Of course, whether the responses provided 
by our participants are unique to this culture, and reflect cultural differences in the experience of autonomy, is a different question, but it is an empirical question: to answer it, the same set of prompts could be given to doctoral students from universities in other countries that represent a range of cultures, and the results compared to what we found.

\section{Conclusion}

The two studies briefly described in the present paper provide support for the use of qualitative research methods as a way to deepen, expand, and potentially challenge how we understand key constructs of a theory, such as SelfDetermination Theory, whose empirical support to date has primarily drawn on quantitative approaches. We note that this may be especially helpful when considering the applicability of key constructs in other cultural settings.

\section{References}

Chirkov, V. I. (2009). A cross-cultural analysis of autonomy in education: A self-determination theory perspective. Theory and Research in Education, 7, 253-262.

Chirkov, V., \& Anderson, J. (2018). Statistical positivism versus critical scientific realism. A comparison of two paradigms for motivation research: Part 2. A philosophical and empirical analysis of critical scientific realism. Theory and Psychology, 28, 737-756. doi:10.1177/0959354318816829

Chirkov, V. I., Ryan, R. M., \& Sheldon, K. M. (2011). Human autonomy in cross-cultural contexts: Perspectives on the psychology of agency, freedom, and well-being. Dordrecht: Springer.

Deci, E. L., \& Ryan, R. M. (1985). Intrinsic motivation and self-determination in human behavior. New York: Plenum.

Jang, H., Reeve, J., Ryan, R. M., \& Kim, A. (2009) Can self-determination theory explain what underlies the productive, satisfying learning experiences of collectivistically oriented Korean students? Journal of Educational Psychology, 101, 644-661.

Lynch, M. F. (2013). Attachment, autonomy, and emotional reliance: A multilevel model. Journal of Counseling and Development, 91, 301-312. doi:10.1002/j.1556-6676.2013.00098.x

Lynch, M. F., La Guardia, J. G., \& Ryan, R. M. (2009). On being yourself in different cultures: Ideal and actual self-concept, autonomy support, and well-being in China, Russia, and the United States. The Journal of Positive Psychology, 4, 290-304.

Lynch, M. F., \& Salikhova, N. R. (2016). Teachers' conceptions about the child's developmental needs: A structural analysis. Mathematics Education, 11, 1471-1479.

Lynch, M. F., \& Salikhova, N. R. (2017). Teachers' beliefs about the needs of students: Teachers as local experts (a qualitative analysis). Education and Self Development, 12, 33-43. doi:10.26907/esd12.3.03

Markus, H. R., \& Kitayama, S. (1991) Culture and the self: Implications for cognition, emotion, and motivation. Psychological Review, 98, 224-253.

Ryan, R. M., \& Deci, E. L. (2017). Self-determination theory: Basic psychological needs in motivation, development, and wellness. New York: Guilford Publications. 
Ryan, R. M., Kuhl, J., \& Deci, E. L. (1997). Nature and autonomy: An organizational view of social and neurobiological aspects of self-regulation in behavior and development. Development and Psychopathology, 9, 701-728. doi:10.1017/S0954579497001405

Ryan, R. M., \& Lynch, J. (1989). Emotional autonomy versus detachment: Revisiting the vicissitudes of adolescence and young adulthood. Child Development, 60, 340-356.

Zhou, M., Ma, W. J., \& Deci, E. L. (2009) The importance of autonomy for rural Chinese children's motivation for learning. Learning and Individual Differences, 19, 492-498.

Martin F. Lynch - Associate Professor, Warner School of Education and Human Development, University of Rochester; Department of General Psychology, the Institute of Psychology and Education, Kazan Federal University; International Laboratory of Positive Psychology of Personality and Motivation, National Research University Higher School of Economics, PhD.

Reseach Area: self-determination theory, basic psychology needs, autonomy support, cross-cultural issues, well-being, development of self, counseling and psychotherapy.

E-mail: mlynch@warner.rochester.edu

Nailya R. Salikhova - Professor, Department of General Psychology, the Institute of Psychology and Education, Kazan Federal University

Reseach Area: psychology of personality, psychology of motivation, developmental psychology.

E-mail: Nailya.Salihova@kpfu.ru

Alina V. Eremeeva - PhD Student, Department of General Psychology, the Institute of Psychology and Education, Kazan Federal University.

Reseach Area: psychology of personality, psychology of motivation.

E-mail: alina_eremeeva@list.ru

\title{
Базовые психологические потребности в разных культурах: использование качественных методов в исследовании ключевых вопросов теории самодетерминации
}

\author{
М.Ф. Линчч, ${ }^{\mathrm{a}, \mathrm{c}}$, Н.Р. Салихова ${ }^{\mathrm{b}}$, А.В. Еремеева ${ }^{\mathrm{b}}$ \\ ${ }^{a}$ Pочестерский университет, 500 Joseph C. Wilson Blvd., Rochester, New York, 14627, USA \\ ${ }^{b}$ Казанский (Приволжский) федеральный университет, 420108, Россия, г. Казань, ул. Кремлевская, \\ ว. 18 \\ 'Национальный исследовательский университет «Высшая школа экономики», 101000, Россия, \\ Москва, ул. Мясницкая, д. 20
}

\section{Резюме}

Теория самодетерминации (SDT) сделала огромные шаги в своем развитии за последние 30 лет. Бо́льшая часть этого прогресса достигнута за счет строгих эмпирических исследований и элегантности самой теории. Все же бо́льшая часть эмпирического подтверждения теории самодетерминации была получена в исследованиях количественного типа, при этом мало внимания до сих пор уделяется возможному вкладу качественного подхода. 
В этой статье подробно описаны два недавних качественных исследования мотивации в сфере образования, направленные на решение критически важных вопросов данной теории. В первом исследовании был поставлен вопрос: «Могут ли быть какие-либо другие базовые психологические потребности в других культурах?» Анализ ответов, которые дали 195 учителей, психологов и директоров школ Республики Татарстан (Россия), показал, что основой психологического благополучия ребенка в их представлении является удовлетворение потребности ребенка в отношениях с другими людьми. Во втором исследовании в центре внимания был вопрос: «Каков опыт автономности для представителей другой культуры?» 115 аспирантов университета (Казань, Россия) описали свой опыт автономности и неавтономности в университете в форме эссе. Анализ позволил выявить две дополнительные категории, различающие эти ситуации между собой: фактор времени и смысл ситуации для человека. В обоих исследованиях участники отвечали в свободной форме своими словами. Эти исследования дают убедительные примеры того, как качественный дизайн может раздвинуть границы современного понимания в отношении центральных вопросов теории самодетерминации в кросс-культурной перспективе. Определены направления для дальнейшего исследования.

Ключевые слова: теория самодетерминации, качественные методы, мотивация, образование, автономность, базовые психологические потребности.

Линч Мартин Ф. - доцент, Рочестерский университ (Рочестер, США); кафедра общей психологии, Институт психологии и образования, Казанский (Приволжский) федеральный университет; Международная лаборатория позитивной психологии личности и мотивации, Национальный исследовательский университет «Высшая школа экономики», PhD. Сфера научных интересов: теория самодетерминации, базовые психологические потребности, поддержка автономии, кросс-культурные исследования, психологическое благополучие, саморазвитие, консультирование и психотерапия.

Контакты: mlynch@warner.rochester.edu

Салихова Наиля Рустамовна - профессор, кафедра общей психологии, Институт психологии и образования, Казанский (Приволжский) федеральный университет, доктор психологических наук, профессор.

Сфера научных интересов: психология личности как субъекта жизни, психология мотивации, психология развития.

Контакты: Nailya.Salihova@kpfu.ru

Еремеева Алина Владимировна - аспирант, кафедра общей психологии, Институт психологии и образования, Казанский (Приволжский) федеральный университет.

Сфера научных интересов: психология личности как субъекта жизни, психология мотивации.

Контакты: alina_eremeeva@list.ru 